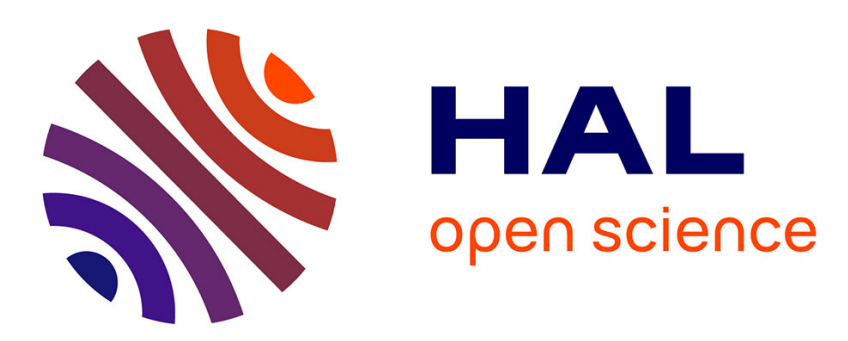

\title{
Migration of plasticizersphthalates, bisphenol A and alkylphenols from plastic containers and evaluation of risk
}

Albert Guart, Francisco Bono-Blay, Antonio Borrell, Silvia Lacorte

\section{- To cite this version:}

Albert Guart, Francisco Bono-Blay, Antonio Borrell, Silvia Lacorte. Migration of plasticizersphthalates, bisphenol $\mathrm{A}$ and alkylphenols from plastic containers and evaluation of risk. Food Additives and Contaminants, 2011, pp.1. 10.1080/19440049.2011.555845 . hal-00677969

\section{HAL Id: hal-00677969 \\ https://hal.science/hal-00677969}

Submitted on 11 Mar 2012

HAL is a multi-disciplinary open access archive for the deposit and dissemination of scientific research documents, whether they are published or not. The documents may come from teaching and research institutions in France or abroad, or from public or private research centers.
L'archive ouverte pluridisciplinaire HAL, est destinée au dépôt et à la diffusion de documents scientifiques de niveau recherche, publiés ou non, émanant des établissements d'enseignement et de recherche français ou étrangers, des laboratoires publics ou privés. 


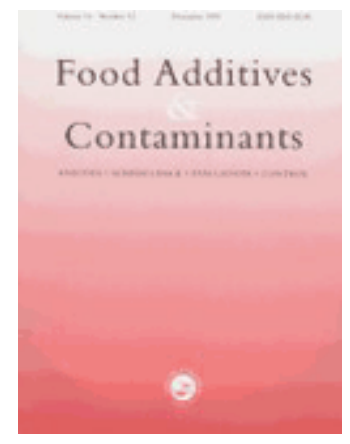

Migration of plasticizersphthalates, bisphenol A and alkylphenols from plastic containers and evaluation of risk

\begin{tabular}{|r|l|}
\hline Journal: & Food Additives and Contaminants \\
\hline Manuscript ID: & TFAC-2010-373.R1 \\
\hline Manuscript Type: & Original Research Paper \\
\hline Author: & 29-Dec-2010 \\
\hline Complete List of Authors: & $\begin{array}{l}\text { Guart, Albert; IDAEA-CSIC; Laboratorio Dr. Oliver-Rodés } \\
\text { Bono-Blay, Francisco; Laboratorio Dr. Oliver-Rodés; IDAEA-CSIC } \\
\text { Borrell, Antonio; Laboratorio Dr. Oliver-Rodés } \\
\text { Lacorte, Silvia; CSIC, Environmental chemistry }\end{array}$ \\
\hline Methods/Techniques: & Chromatography - GC/MS, Extraction, Method validation \\
\hline Additives/Contaminants: & $\begin{array}{l}\text { Packaging - bisphenol A, Environmental contaminants - Alkyl } \\
\text { Phenols, Migration, Packaging - DEHP (phthalates) }\end{array}$ \\
\hline Food Types: & Water \\
\hline \multicolumn{2}{|l}{} \\
\hline
\end{tabular}

\section{SCHOLARONE \\ Manuscripts}


1 Migration of phthalates, bisphenol $\mathrm{A}$ and alkylphenols from plastic 2 containers and evaluation of risk

4 Albert Guart $^{\mathrm{a}, \mathrm{b}}$, Francisco Bono-Blay ${ }^{\mathrm{a}, \mathrm{b}}$, Antonio Borrell ${ }^{\mathrm{b}}$ and Silvia Lacorte $^{\mathrm{a}}$

5 a Department of Environmental Chemistry, IDAEA-CSIC, Jordi Girona 18-26, 08034

6 Barcelona, Catalonia, Spain

7 b Laboratorio Dr. Oliver-Rodés, Moreres, 21 (Polígon Estruc), 08820 El Prat de

8 Llobregat, Spain

Keywords: migration; plasticizer; phthalate; alkylphenol; bisphenol A; nonylphenol;

\section{Abstract}

This study has investigated the potential migration of plasticizers, plastic components and additives from several plastic water bottles. Compounds studied were phthalates (dimethyl phthalate, di-n-butyl phthalate, benzylbutyl phthalate, bis(2-ethylhexyl) phthalate), bis(2-ethylhexyl) adipate, octylphenol, 4-nonylphenol and bisphenol A. Polycarbonate (PC), high density polyethylene (HDPE), low density polyethylene (LDPE), polyethylene terephthalate (PET) and polystyrene (PS) plastics used in the water bottling sector were tested using three kinds of total or specific migration tests: i) standard method UNE-EN ISO 177; ii) ultrasonic forced extraction and iii) standard method UNE-EN 13130-1. In addition, bottled waters contained in different plastic materials were analyzed to determine the potential migration of target compounds in real conditions. In all cases, samples were solid phase extracted using Oasis HLB 200 mg cartridges and analyzed using GC-MS in scan acquisition mode. Bisphenol A and 4nonylphenol were detected in incubated samples, indicating that migration from food plastics can occur at the experimental conditions tested. The total daily intake was calculated according to the levels detected in bottled water and the assessment of the consumers' risk was evaluated taking into consideration toxicological and legislative values. SPE; GC-MS. 


\section{Introduction}

In the last years there has been an increase in the use of plastic materials in the food sector and consumer products, both for primary and secondary packaging. In the bottling industry, bottles are manufactured from specific polymers depending on the capacity of the container, each of them with unique characteristics as regards bottle strength, storage time, type of dispenser and disposal. Primary packaging is made with high density polyethylene (HDPE), polyethylene terephthalate (PET) and polycarbonate (PC) while caps are made of high density polyethylene (HDPE), low density polyethylene (LDPE) and polystyrene (PS) is used as septa in many caps (World Packaging Organization (WPO) 2008). These polymers contain additives such as antifogging, reinforcing and antistatic agents, blowing agents, colorants, fillers, lubricants, nucleating agents, optical brighteners, heat and light stabilizers, antiacids, antimicrobials, antioxidants, chain-breaking, photo- and hydroperoxide deactivating antioxidants, dehydrating agents, light screening pigments and UV absorbers (Bolgar 2008; Piringer 2008). Mixtures of plastic components and additives can be made to obtain improved plastic characteristics. In addition, several water bottle formats, shapes and colours are used in the different bottling industries.

The safety of some of polymeric materials is nowadays a subject of concern in the bottling sector due to the potential migration of plasticizers and additives to water by a diffusion process (Biscardi et al. 2003), as described for bisphenol A (BPA) (Biles et al. 1997; Casajuana et al. 2003; Le et al. 2008; Loyo-Rosales et al. 2004), phthalates (Casajuana et al. 2003; Peñalver et al. 2000) or nonylphenol (NP) (Casajuana et al. 2003). These substances are either plastic components, such as BPA used as monomer in the production of polycarbonate bottles (the so called "coolers"), or additives used to improve the plastic properties (such as NP), polymerization accelerators or agents to increase flexibility (phthalates) (Casajuana et al. 2003; Loyo-Rosales et al. 2004; Peñalver et al. 2000; Shen et al. 2007).

The presence of plastic components or additives in water can modify the organoleptic properties and if present at high concentrations, may trigger health problems due to the potential toxic properties of some chemicals. Epidemiological studies in test animals indicate an increase of some kinds of cancer, behaviour changes and anomalies in the reproductive and immunologic functions of some species (Casajuana et al. 2003; Rivas et al. 1997), reason that some of the target compounds are considered as endocrine disruptor compounds (EDC). Possible human health endpoints 
affected by these agents include breast cancer and endometriosis in women, testicular and prostate cancers in men, abnormal sexual development, reduced male fertility, alteration in pituitary and thyroid gland functions, immune suppression, and neurobehavioral effects (Environmental Protection Agency (EPA) 1997). For safety reasons, polymers used for packaging which are in contact with food must be analyzed before use to prevent migration of any of its components to the food (Council of Europe 2002).

Several methods are used to evaluate the potential migration of plastic components or additives. The migration capacity varies depending on conditions used in migration tests and depending on the type of food simulant. Nerín et al. (2002) used different migration tests, one consisted in two sorbents (Tenax and Porapak) in contact with plastic, and another consisted in a total dissolution procedure with dichloromethane and methanol (Nerín et al. 2003). These migration tests were set up for several plastic containers used in microwave ovens. Schmidt et al. performed a quantitative determination of the plasticizers bis(2-ethylhexyl) adipate (DEHA) and bis(2-ethylhexyl) phthalate (DEHP) in PET bottles and revealed maximum concentrations of 0.046 and $0.71 \mu \mathrm{g} \mathrm{L}^{-1}$, respectively (Schmid et al. 2008). Casajuana et al. (2003) detected BPA in HDPE and PET bottles at levels between 0.003 and $0.011 \mu \mathrm{g}$ $\mathrm{L}^{-1}$ after exposing water bottles at sunlight for 10 weeks. BPA was also detected in waters of public distribution system at levels of 0.006 and $0.025 \mu \mathrm{g} \mathrm{\textrm {L } ^ { - 1 }}$. The same authors analyzed BPA in milk packed in Tetra Pack or HDPE bottles and concentrations were between 0.28 and $2.64 \mu \mathrm{g} \mathrm{kg}^{-1}$ of milk, depending on the brand (Casajuana et al. 2004). This indicates that fatty foods have a better ability to extract BPA from plastics than water.

This study has investigated the potential migration of plasticizers and additives from several plastic containers. Three migration tests were conducted: i) the standard method UNE-EN ISO 177 to test overall migration from plastics (not necessarily food contact materials) where plastics are in contact with an adsorbent and incubated at $40^{\circ} \mathrm{C}$ during 10 days (European Communities 1988); ii) ultrasonic forced extraction of plastics incubated in water at different times and iii) the standard method UNE-EN 13130 (2005, Part 1) in which plastics were incubated at $40^{\circ} \mathrm{C}$ in water for 10 days. This last method is described and legislated in the Spanish Royal Decree 866/2008 (Ministerio de la Presidencia 2008) transposing Directives 82/711/EC (The Commission of the European Communities 1982), 85/572/CEE (The Commission of the European 
102 Communities 1985), UNE-EN 1186 of 2002 and 2007/19/CE (The Commission of the

103 European Communities 2007). Analyses were performed using solid phase extraction

104 (SPE) followed by gas chromatography coupled to mass spectrometry (GC-MS).

\section{Materials and methods}

108 Chemicals and reagents

109 Five phthalates, two alkylphenols and BPA were analyzed (Table 1). Analytical grade 110 (98\% purity) Phthalate Esters Mix including dimethyl phthalate (DMP), di-n-butyl 111 phthalate (DPB), butyl benzyl phthalate (BBP), bis(2-ethyhexyl) phthalate (DEHP) and 112 bis(2-ethyhexyl) adipate (DEHA) was purchased from Supelco (Bellefonte, PA, USA) 113 at a concentration of $500 \mu \mathrm{g} \mathrm{mL}^{-1}$ each in methanol. 4-nonylphenol (NP) was from 114 Riedel-de Haën (Seelze, Germany) as a solid technical mixture of isomers; 4-tert115 octylphenol (OP) was from Supelco (Bellefonte, PA, USA) as a solid and BPA was 116 from Dr. Ehrenstorfer (Augsburg, Germany) as a solid. Stock standard solutions of each 117 compound were prepared in ethyl acetate at a concentration of $5 \mu \mathrm{g} \mathrm{mL}^{-1}$ and stored in 118 the dark at $-20^{\circ} \mathrm{C}$ until use. The surrogate standards used were NP- $\mathrm{d}_{8}\left(100 \mathrm{ng} \mu \mathrm{L}^{-1}\right)$, 119 diphenylphthalate- $\mathrm{d}_{4}\left(\mathrm{DPP}-\mathrm{d}_{4}\right)$ and BPA- $\mathrm{d}_{16}$ purchased as solids from Dr. Ehrenstorfer 120 (Augsburg, Germany). The internal standard was anthracene- $\mathrm{d}_{10}$, purchased from 121 Supelco.

$122200 \mathrm{mg}$ Oasis HLB cartridges were from Waters (Milford, MA, USA) and used 123 with a Baker vacuum system (prod. No. 7018-94, J.T. Baker, The Netherlands). 124 Chromatography grade methanol, acetone, dichloromethane, n-hexane, ethyl acetate and HPLC water were purchased from Merck (Darmstadt, Germany).

127 Samples

128 Polyethylene terephthalate (PET), polycarbonate (PC), two types of high density 129 polyethylene (HDPE), low density polyethylene (LDPE) and polystyrene (PS) plastics 130 used as cap septa were tested using three kinds of migrations test (see below). Prior to 131 use, these plastics were rinsed with HPLC water and cut with scissors in circular chips 132 of different diameter, according to the migration test used. In addition, bottled water 133 samples in PET, PC and HDPE were analyzed to determine the presence of target 134 compounds in real storing conditions. 


\section{Migration tests}

137 Three methods were used to test the migration of phthalates, BPA and 138 alkylphenols from water bottles, taps and septa. Except for UNE-EN ISO 177, specific 139 migration tests were performed for all plastic types for comparability purposes. 140 Although article filling is a conventional test to evaluate the migration of plastic 141 components, total immersion was used because in our laboratory conditions, it was 142 impossible to perform migration test of containers as big as $18 \mathrm{~L}$ (e.g. coolers). 143 According to the specific migration test performed, values are given in $\mu \mathrm{g} \mathrm{dm}^{-2}$ because 144 the samples were extracted from bottles as sheets and not as filled samples (Table 3). 145 Also, the migration tests used in this study can be considered as total immersion tests, 146 where the two plastic layers, inside (in contact with food) and outside (in contact with 147 the environment) are in contact with the food stimulant. In European standards, it is 148 considered the most severe test.

149 All sample manipulation was done using polytetrafluoroethylene (PTFE) tubing and glass material to avoid external contamination of the samples.

UNE-EN ISO 177 method was used as a screening tool for the determination of the overall migration of plasticizers, expressed as loss of weight in the incubated plastic and gain in the adsorbent. It applies to evaluate the tendency of plasticizers and additives to migrate from plastic materials to other materials placed in close contact with them. It cannot be compared with food legislation, although it shows the possible migration of plasticizers and represented the starting point for the next tests. First, $\mathrm{C}_{18}$ disks of $47 \mathrm{~mm}$ diameter and the plastic samples cut at the same diameter were weighed. The plastic sample was placed in a "sandwich" made of the plastic chip placed in between two $\mathrm{C}_{18}$ adsorbent disks, as it is shown in Figure 1. The "sandwich" was placed under a weight of $5 \mathrm{~kg}$, and was introduced in an oven at $40^{\circ} \mathrm{C}$ during 10 days, as described in Directive 82/711/EC and their modifications (Directive 93/8/EC and Directive 97/48/EC). After that, the "sandwich" was removed and the adsorbent disks and samples were re-weighed to determine the weight difference. All polymers were tested except LDPE and PS sample which were adhered to the sorbent and could not be weighed after incubation.

166 Ultrasonic extraction method was developed as an accelerated method to force 167 the migration of plastic components and additives to water. Although the results 168 obtained in this method are not comparables with legislated values, it permits to identify 169 the compounds that tend to migrate. $1 \mathrm{~g}$ of $0.5-1 \mathrm{~cm}^{2}$ plastic chips was introduced in 
$170100 \mathrm{~mL}$ of unbuffered HPLC water (used as food simulant at $\mathrm{pH}>4.5$, as described in 171 Directive 82/711/EC), and 5 ng of surrogates standards were added. Then samples were 172 incubated in an ultrasonic bath during 5, 10 and $15 \mathrm{~min}$ (Figure 1). Afterwards, $100 \mathrm{~mL}$ 173 of the incubated water was solid phase extracted (Céspedes et al. 2004) and analyzed by 174 GC-MS to identify target compounds. All assays were performed in triplicate.

175 UNE-EN 13130 method was used for the identification of plastic components 176 and to compare the concentrations obtained with legislated values (Table 1). $1 \mathrm{~g}$ of 177 plastic chips was introduced in $100 \mathrm{~mL}$ of unbuffered HPLC water (used as food 178 simulant at $\mathrm{pH}>4.5$, as described in Directive 82/711/EC) and $5 \mathrm{ng}$ of surrogates 179 standards were added. Samples were incubated in a water bath at a temperature of $40^{\circ} \mathrm{C}$ 180 during 10 days (Figure 1). After incubation, water was extracted by SPE and analyzed 181 by GC-MS. GC-MS was used because it permitted to simultaneously analyze 182 phthalates, alkylphenols and BPA, although UNE-EN 1313-13 describes the 183 determination of BPA in food stimulants by high performance liquid chromatography 184 (HPLC) with ultraviolet (UV) detection. All assays were performed in triplicate.

\section{Solid Phase Extraction procedure}

187 Resulting water from the migration tests was solid phase extracted using $200 \mathrm{mg}$ Oasis 188 HLB SPE cartridges using a Baker vacuum system with 12 cartridges capacity. All 189 Baker vacuum system connections and tubing were of PTFE to avoid contamination of 190 target compounds. Cartridges were conditioned prior to sample loading with $10 \mathrm{~mL}$ of 191 hexane, followed by $10 \mathrm{~mL}$ of dichloromethane, $10 \mathrm{~mL}$ of methanol and $15 \mathrm{~mL}$ of 192 HPLC water, all by gravity. This extensive cartridge cleaning was performed to 193 eliminate any traces of target compounds. Then, $100 \mathrm{~mL}$ of water were preconcentrated 194 at a flow of 8-13 $\mathrm{mL} \mathrm{min}^{-1}$ and afterwards the cartridge was dried under vacuum during 1951 hour. Elution was performed with $10 \mathrm{~mL}$ of dichloromethane:hexane (1:1) and $10 \mathrm{~mL}$ 196 dichloromethane:acetone (1:1). The extract was preconcentrated in a Turbovap nitrogen 197 evaporator and extracts were reconstituted with $240 \mu \mathrm{L}$ of ethyl acetate and $10 \mu \mathrm{L}$ of 198 anthracene $\mathrm{d} 10\left(10 \mathrm{ng} \mu \mathrm{L}^{-1}\right)$ was added as internal standard.

\section{$200 \quad$ Instrumental analysis}

201 Samples were analysed by gas chromatography coupled to a quadrupole mass 202 spectrometer (Trace GC-2000 series from Thermo Electron, San José, CA, USA). The 203 system was operated in electron ionization mode (EI $70 \mathrm{eV}$ ). The separation was 
achieved with a $30 \mathrm{~m} \times 0.25 \mathrm{~mm}$ I.D. DB-5MS column (J\&W Scientific, Folsom, CA,

205

206

207

208

209

210

211

212

213

214

215

216

217

218

219

220

221

222

223

224

225

226

227

228

229

230

231

232

233

234

235

236

237 USA) coated with $5 \%$ phenyl-95\% dimethylpolysiloxane (film thickness $0.25 \mu \mathrm{m}$ ). The oven temperature was programmed from $70^{\circ} \mathrm{C}$ (holding time $2 \mathrm{~min}$ ) to $135^{\circ} \mathrm{C}$ at $10^{\circ} \mathrm{C}$ $\mathrm{min}^{-1}$, to $160^{\circ} \mathrm{C}$ at $3^{\circ} \mathrm{C} \mathrm{min}^{-1}$, to $175^{\circ} \mathrm{C}$ at $1^{\circ} \mathrm{C} \min ^{-1}$, to $195^{\circ} \mathrm{C}$ at $3^{\circ} \mathrm{C} \mathrm{min}{ }^{-1}$ and finally to $310^{\circ} \mathrm{C}$ at $10^{\circ} \mathrm{C} \min ^{-1}$, keeping the final temperature for $5 \mathrm{~min} .2 \mu \mathrm{L}$ were injected in the splitless mode, keeping the split valve closed for $1 \mathrm{~min}$. Helium was the carrier gas (1.2 $\left.\mathrm{mL} \min ^{-1}\right)$. Injector, GC interface temperature and ion source temperatures were $280^{\circ} \mathrm{C}$, $280^{\circ} \mathrm{C}$ and $200^{\circ} \mathrm{C}$, respectively.

Peak detection and integration were carried out using Xcalibur software. Full scan data (from m/z 60 to 400) was used for the identification of target compounds in the migration tests.

\section{Quantification and quality parameters}

Internal standard quantification was performed using the deuterated surrogate standards corresponding to each chemical family (alkylphenols, phthalates and BPA) to correct any lose during sample manipulation. Calibration curves were constructed for all target compounds over a concentration of $0.01-1 \mathrm{mg} \mathrm{L}^{-1}$. Limits of detection (LOD) were calculated using 3 times the standard deviation of $n=5$ blank samples, which is an adequate procedure when there is a contribution of target compounds in the blank samples due to the extraction and MS analysis. This procedure provides higher LOD than when calculated from a spiked sample at low concentration and using 3 times the noise signal. However, it is more realistic and provides better accuracy by reducing the risk of overestimation due to sample contamination by the ubiquitous presence of phthalates in laboratory air and even in the MS injection port. Quality controls were performed using HPLC water spiked at $1 \mu \mathrm{g} \mathrm{L}^{-1}$ and were incubated in the absence of any plastic using the ultrasonic extraction and the UNE-EN 13130 method, in triplicate and using closed glass containers.

\section{Results}

\section{Performance of the 3 migration tests}

Migration tests permit to assess the potential leaching or migration of plastic components or additives. The UNE-EN ISO 177 method was used as a screening tool to determine the migration of plasticizers but was not adequate to identify specific 
238 compounds. To identify those compounds that migrate from plastic and quantify their 239 levels, ultrasonic and incubation of plastics at $40^{\circ} \mathrm{C}$ were used in combination of GC240 MS whose capabilities permitted the determination of target compounds from test 241 materials with good performance as regards to identification and precise quantification. 242 The identification of plastic components was done in scan acquisition mode, which 243 provided high selectivity and good identification capabilities and no response 244 enhancement was observed due to the migration of other polymerized plastic to the 245 extracts. The method allowed the determination of target analytes in water samples at 246 levels of sub $\mu \mathrm{g} \mathrm{L}^{-1}$ (Table 1). The LOD of phthalates were high compared to other 247 studies (Peñalver et al. 2000) because they were calculated from the 3 times the 248 standard deviation of the blank samples which always contained traces of phthalates that 249 originate both from the extraction and from the GC injection port. The use of surrogate 250 standards to quantify each compound was necessary to achieve accurate results, taking 251 into consideration the loss of analytes during incubation or extraction. The recoveries of 252 the analytes were between 93 and $125 \%$ for the SPE-GC/MS method (Table 1).

\section{Migration of plastic components and additives from bottled water and caps}

UNE-EN ISO 177 provides an unspecific method capable to determine the total mass of compounds migrating from plastic containers. Table 2 proves that tested plastics incubated at $40^{\circ} \mathrm{C}$ lost weight, which was gained by the adsorbent, although there was some mismatch due to the fact that some volatile compounds were lost during incubation at $40^{\circ} \mathrm{C}$, as considered in UNE-EN ISO 177. For example, for the PC plastic, there was a $0.1 \mathrm{mg}$ increase in the plastic due to humidity increase in the weighing process but the gain of $2.3 \mathrm{mg}$ in the sorbent after incubation should be taken into consideration. Overall, the lose in plastic weight provides first evidence on the overall migration of plasticizers from incubated plastics although this method failed to identify and quantify specific compounds prone to migrate.

Migration tests UNE-EN 13130 and ultrasonic incubation were able to identify target compounds. Ultrasonic method is a fast extraction method and was developed in an attempt to validate it by comparing the results with the incubation at $40^{\circ} \mathrm{C}$. We found that qualitatively, both methods provided similar information, but quantitatively, compounds were extracted with different efficiency. Phthalates were not detected in any

270 of the plastics tested and in any of the treatments used, and indicates that either these compounds were not added in the tested plastics or either that they do not migrate at the 
272 conditions tested. The same holds for octylphenol. NP and BPA were the only 273 compounds identified. The recoveries of NP and BPA using the ultrasonic incubation were of $45 \%$ and $76 \%$ for respectively, and using the UNE-EN 13130, recoveries were 92\% and $97 \%$ for NP and BPA, respectively. The different recoveries using both migration tests reflect the losses that occur during the incubation period, which are higher when using ultrasonic extraction, especially for NP.

Ultrasonic incubation forces the migration of compounds by applying an ultrasonic wave which enhances the detachment of plastic components or additives which are released to water. Results showed that there was not any difference in the migration of plastic compounds using different extraction times $(5,10$ or $15 \mathrm{~min})$ and thus, an extraction time of 5 min was chosen. Using this technique, NP was identified in the incubated plastics at levels of $0.212-0.242 \mu \mathrm{g} \mathrm{dm}{ }^{2}$ while BPA was only detected at $1.870 \mu \mathrm{g} \mathrm{dm}^{2}$ in the PC plastic (Table 3).

UNE-EN 13130 describes the methods for determining the specific migration of plastic materials and UNE-EN 1186 describes the methods for determining the overall migration of materials, plastics and articles in contact with foodstuffs. This UNE-EN 13130 migration test was based on Part 1, guide to test methods for the specific migration of substances from plastics (see also UNE-EN 1186, Part 1 guide for the selection of conditions and test methods to calculate the overall migration). Using this method, NP and BPA were quantified at levels of 0.332-1.282 $\mu \mathrm{g} \mathrm{dm}^{2}$ and 0.128-3.423 $\mu \mathrm{g} \mathrm{dm}{ }^{2}$, respectively (Table 3 ). This method was more efficient in extracting plasticizers and additives from plastics than ultrasonic extraction, and was able to determine NP in all types of plastic and BPA in PC, HDPE, LDPE and PS. Both NP and BPA can be used as plastic additives to improve the quality of plastic.

These two last methods are complementary and provide similar information on the migration potential, qualitatively. Ultrasonic bath provides a lower migration of BPA and NP compared to the UNE-EN 13130 (Table 3). Among both methods, ultrasonic extraction can be considered a fast extraction method but with lower efficiency than UNE-EN 13130 and so far, is not validated yet. Most important is that UNE-EN 13130 is based on a technical interpretation of Directive 2007/19/EC and provides maximum legislated migration levels for a large number of compounds. Thus, this technique was further used to determine the migration levels of target compounds in the 5 polymers studied and to compare the specific migration levels with legislated values. 
307 Polymers tested and migration levels according to UNE-EN 13130

308 NP and BPA were the only compounds identified in PC, HDPE, LDPE and PS plastics 309 and for PET and HDPE bottles NP was the only compound identified. The MS 310 chromatogram of BPA in the PC sample with UNE-EN 13130 method is shown in 311 Figure 2. PET was the plastic type for which NP migration was lower, followed by 312 HDPE bottles and PC. For caps material, NP levels increased from LDPE $<$ PS $<$ HDPE 313 with NP migration between $0.413 \mu \mathrm{g} \mathrm{dm}^{-2}$ and $1.282 \mu \mathrm{g} \mathrm{dm}^{-2}$. Contrarily, BPA was not 314 detected in PET or HDPE bottles while the highest migration was found in PC bottles at $3153.423 \mu \mathrm{g} \mathrm{dm}^{-2}$. BPA was also detected in caps and septa with levels ranging from 0.128 $316 \mu \mathrm{g} \mathrm{dm}^{-2}$ to $0.145 \mu \mathrm{g} \mathrm{dm}^{-2}$.

317 PET is one of the most common polymers used in bottled water container for its 318 lightness, its gas barrier and its possibility to be recycled, and it is generally used in 319 volumes from 0.33 up to $8 \mathrm{~L}$ bottles. Although in general it is for a single use, some 320 companies recycle up to $25 \%$ of this plastic in the manufacture of new bottles. NP was 321 detected at a mean concentration of $0.332 \mu \mathrm{g} \mathrm{dm}^{-2}(\mathrm{n}=3)$ and BPA was not detected in 322 any replicate in this kind of plastic (Table 3). Casajuana et al. (Casajuana et al. 2003) 323 found the presence of DMP, DEP, 4-NP, DBP, BPA, BBP and DEHP in PET bottled 324 water samples at levels of 0.002 to $0.214 \mu \mathrm{g} \mathrm{L}^{-1}$ after 10 weeks storage at high 325 temperature and using SPE-GC-MS. Contrarily, Loyo-Rosales et al. (Loyo-Rosales et 326 al. 2004) describe that neither NP nor OP were found in extracts from water stored in 327 PET containers after $240 \mathrm{~h}$. This discrepancy is attributed to the migration test and 328 conditions used. NP is not legislated by the European Community and thus, a 329 comparison with maximum permissible levels cannot be withdrawn.

330 HDPE is characterized by its strength and resistance to many solvents and is 331 used in bottles of 5-8 L. This material is also used in the manufacture of caps, since it is 332 resistant and it has a good sealing capacity. NP was released at concentrations $0.579 \mu \mathrm{g}$ $333 \mathrm{dm}^{-2}$ and $1.282 \mu \mathrm{g} \mathrm{dm}{ }^{-2}$ for HDPE bottles and caps, respectively (Table 3 ). For HDPE 334 caps, BPA was detected at $0.145 \mu \mathrm{g} \mathrm{dm}^{-2}$ and no traces were found in HDPE bottles 335 (Table 3). Other studies describe the presence of NP in water bottled in HDPE and PVC 336 containers at a concentration of $0.230 \mu \mathrm{g} \mathrm{L}^{-1}$ after $120 \mathrm{~h}$ at $40^{\circ} \mathrm{C}$ (Loyo-Rosales et al. 337 2004).

338 PC, a more resistant plastic, is used in containers over $10 \mathrm{~L}$ capacity and after 339 use, it is cleaned and reused. PC plastic is made of BPA monomers, which can migrate 
340 from containers (Le et al. 2008). The BPA amount detected in PC plastic was of 3.423 $341 \mu \mathrm{g} \mathrm{dm}^{-2}$ and NP was detected at $0.694 \mu \mathrm{g} \mathrm{dm}^{-2}$. Another study using bottled water in PC 342 describes the migration of this compound from used and new bottles at $0.7 \mu \mathrm{g} \mathrm{L}^{-1}$ and $3431.0 \mu \mathrm{g} \mathrm{L}^{-1}$, respectively, after 7 days at room temperature (Le et al. 2008). Nerín et al. 344 (Nerín et al. 2003) detected that BPA migrated from PC plastic stored at room 345 temperature. Biles et al. (Biles et al. 1997) detected BPA in PC baby bottles and cups at 346 levels ranging from non detected to $5 \mu \mathrm{g} \mathrm{L}^{-1}$.

LDPE is the polymer used in the cooler caps, its structure is the same as HDPE but the density is lower so LDPE is used in caps and not in bottles. NP and BPA migrated as shown in Table 3 at levels of 0.413 and $0.128 \mu \mathrm{g} \mathrm{dm}^{-2}$, respectively.

Finally, PS was tested because it is used in the septum of several caps, such as the ones used in coolers. The amounts detected were 0.801 and $0.136 \mu \mathrm{g} \mathrm{dm}^{-2}$ for NP and BPA, respectively. PS is one of the most produced plastics in food contact materials and can be copolymerized with many monomers. Products formed from PS are hard and transparent (Piringer 2008). However, cap septa are whitish due to additives that improve the brittleness and the sensitivity to stress cracking (Piringer 2008). These additives may migrate as it happens in other type of plastics.

The presence of phthalates and BPA in food in contact with plastic is legislated in the European Union. Directive 2002/72/EC, Directive 2004/19/EC and Directive 2007/19/EC (transposed to the Spanish Royal Decree 866/2008) establishes migration specific limits in food and food simulants of $600 \mu \mathrm{g} \mathrm{kg}^{-1}$ or $100 \mu \mathrm{g} \mathrm{dm}^{-2}$ for BPA, 1500 $\mu \mathrm{g} \mathrm{kg}^{-1}$ or $250 \mu \mathrm{g} \mathrm{dm}^{-2}$ for DEHP, $300 \mu \mathrm{g} \mathrm{kg}^{-1}$ or $50 \mu \mathrm{g} \mathrm{dm}^{-2}$ for DBP and $30000 \mu \mathrm{g} \mathrm{kg}^{-}$ ${ }^{1}$ or $5000 \mu \mathrm{g} \mathrm{dm}^{-2}$ for BBP. The levels for phthalates are explicit in Directive 2007/19/EC and are different according to i) whether the packing is a single or multiple use article, ii) whether it is in contact with aqueous or fatty foods and 3) whether it is for infants. So there are a variety of limits for different cases. From the different polymers tested, none of the samples exceeded the legislated value of $100 \mu \mathrm{g} \mathrm{dm}^{-2}$ for BPA. These legislated levels are lower or equal with the former Directive 2002/72/EC, who established migration specific limits in food and food simulants of $3000 \mu \mathrm{g} \mathrm{kg}^{-1}$ for BPA and $1500 \mu \mathrm{g} \mathrm{kg}^{-1}$ for DEHP. Specifically, the levels of BPA decreased 5 times from 2002 to 2007 Directives because the increasing information and studies on BPA toxicity and the potential effects on humans if ingested daily (Bredhult et al. 2009; 


\section{Analysis of bottled water}

375 The presence of plasticizers in bottled water (PET, HDPE and PC) was determined using the same SPE-GC/MS method extracting $1 \mathrm{~L}$ of water. In 1.5 L PET bottles, 2 out of 10 samples contained one target compound; OP was detected in one sample at 0.003 $\mu \mathrm{g} \mathrm{L}^{-1}$ and NP in another at $0.019 \mu \mathrm{g} \mathrm{L}^{-1}$. In HDPE bottles, OP was detected in two samples at $0.003 \mu \mathrm{g} \mathrm{L}^{-1}$ and $0.004 \mu \mathrm{g} \mathrm{L}^{-1},(\mathrm{~N}=7$, volume $=5-10 \mathrm{~L})$. The trace presence of these compounds is attributed to the use of OP and NP in the production of the specific polymers which vary among brands.

Finally, all PC coolers $(\mathrm{N}=10$, volume $=18.9-20 \mathrm{~L})$ contained BPA at levels ranging from $1.60 \mu \mathrm{g} \mathrm{L}^{-1}$ to $4.44 \mu \mathrm{g} \mathrm{L}^{-1}$, with an average concentration of $2.64 \mu \mathrm{g} \mathrm{L}^{-1}$.

384 These levels are in agreement with other studies which indicate that BPA can migrate from both PC and epoxy resins containers in contact with water at levels of few $\mu \mathrm{g} \mathrm{L}^{-1}$. In a former study regarding the migration of BPA, the U.S. FDA (Food \& Drug Administration of the United States) analyzed BPA in water coolers stored for 39 weeks and found BPA at levels between 0.1 and $4.7 \mu \mathrm{g} \mathrm{L}^{-1}$ (Environmental Protection Agency (EPA) 1993). In a 1997 study, it was found that BPA migrated when exposing polymeric material to water, ethanol/water and Miglyol (an oil) to temperatures of $65^{\circ} \mathrm{C}$ for 10 days. In the case of water in contact with polycarbonate bottles where the BPA is the main monomer, the levels of BPA were from not detected to $5 \mu \mathrm{g} \mathrm{L}^{-1}$ (Biles et al. 1997). In another study, the migration of BPA in PC bottles filled with water and exposed to $100^{\circ} \mathrm{C}$ for $1 \mathrm{~h}$ showed BPA migration levels of $0.23 \pm 0.12 \mu \mathrm{g} \mathrm{L}^{-1}$, while levels increased to $8.4 \pm 4 \mu \mathrm{g} \mathrm{L}^{-1}$ and $6.7 \pm 4 \mu \mathrm{g} \mathrm{L} \mathrm{L}^{-1}$ after using a domestic dishwasher between 51 and 169 times (Unit on food contact materials, enzymes, flavourings and processing aids (CEF) et al. 2008).

\section{Daily Intake and toxicological values}

400 The Tolerable Daily Intake (TDI) is a set of reference values for the acceptable intake of 401 a variety of nutrients, as well as energy. A way to express the toxicity of a chemical 402 specie is to calculate the TDI, which represents a lifetime exposure level that is 403 considered to be safe. In this study, BPA is the only compound considered for 404 evaluating the TDI since it was the only one detected in all samples analyzed. Based on 405 the migration data from bottled water, the total exposure to BPA from PC plastic was 406 estimated to be of $4.0010^{-5} \mathrm{mg} \mathrm{BPA} \mathrm{kg}^{-1} \mathrm{bw} \mathrm{day}^{-1}$ (1.5 $\mathrm{L}_{\text {water day }}{ }^{-1}, 60 \mathrm{~kg}$ person and $\left.4071.60 \mu \mathrm{g} \mathrm{BPA} \mathrm{L}^{-1}\right)$ and an upper range exposure of $1.4810^{-4} \mathrm{mg} \mathrm{BPA} \mathrm{kg}^{-1}$ bw day ${ }^{-1}(2 \mathrm{~L}$ 
408 water day ${ }^{-1}, 60 \mathrm{~kg}$ person and $4.44 \mu \mathrm{g} \mathrm{BPA} \mathrm{L}{ }^{-1}$ ). The Scientific Committee on Food 409 (SCF) in 2002 considered that the overall oral No-Observed-Adverse-Effect Level 410 (NOAEL) for BPA was $5 \mathrm{mg} \mathrm{kg}^{-1}$ bw day ${ }^{-1}$ and set a temporary TDI of $0.01 \mathrm{mg} \mathrm{kg}^{-1}$ 411 bw day $^{-1}$ (European Food Safety Authority (EFSA), 2006), which was changed in 2008 412 by a TDI of $0.05 \mathrm{mg} \mathrm{kg}^{-1}$ bw day ${ }^{-1}$ (Unit on food contact materials, enzymes, 413 flavourings and processing aids (CEF) et al. 2008). In a former study realized in 1993, 414 the U.S. EPA had already suggested a reference value of $0.05 \mathrm{mg} \mathrm{kg}^{-1}$ of body weight 415 (Environmental Protection Agency (EPA) 1993). These organizations state that PC 416 products are safe for being used in products in contact with food and beverage and pose 417 no known risk to human health. The levels of BPA from PC coolers were below the 418 NOAEL and TDI, although it should be considered that BPA consumption from PC 419 bottled water is only a part of the total oral Daily Intake.

420 Many studies have been carried out on the toxicity and potential estrogenic 421 effects of BPA using various animal models, cellular lines and at molecular and 422 biochemical level. These studies set the initial basis to carry out risk assessment studies 423 of BPA on humans. However, discrepancies have been observed in these on going 424 studies regarding both the effects of BPA and the levels that cause these effects. From a 425 toxicological point of view, if the aquatic toxicity is considered using Daphnia magna, $426 \mathrm{EC}_{50}$ values range between 1 and $20 \mathrm{mg} \mathrm{L}^{-1}$ (Table 1), and although these 427 concentrations cannot be extrapolated to a human model toxicity, they are an indicator 428 that effects caused to a very sensitive specie are initiated at the mg level. Cespedes et al. 429 developed a more specific method to assess the estrogenicity of BPA using recombinant 430 yeast using the human estrogen receptor (Céspedes et al. 2004). It was demonstrated 431 that the estrogenicity of BPA is $1644 \pm 380 \mu \mathrm{g} \mathrm{L}^{-1}$, much lower than the natural 432 hormone estradiol $\left(0.04 \mu \mathrm{g} \mathrm{L}^{-1}\right)$, used as positive control (Table 1$)$. That means that at 433 concentrations below $1644 \mu \mathrm{g} \mathrm{L}^{-1}$, BPA does not activate the human estrogen receptor 434 and therefore does not trigger any estrogenic effect. Concluding, the concentration of 435 BPA from PC containers in the samples analyzed were below the aquatic toxicity, the $436 \mathrm{EC}_{50}$ obtained with the recombinant yeast assay and the legislated levels (Table 1). 437 However, epidemiological studies carried out by Vandenberg et al. indicate that BPA is 438 present in human fluids at concentration levels higher than those that induce effects in 439 vitro and one order of magnitude higher than the levels that induce effects in animal 440 models (Vandenberg et al. 2007). Another study detected that $92.6 \%$ of the examined 
441 US population had BPA in urine due to the routine ingestion of this compound from 442 plastic food containers (Calafat et al. 2008).

443

444

445

\section{Conclusions}

447 Given the increased use of plastic in the bottling packaging sector, migration tests 448 permit the identification of plasticizers and additives with endocrine disrupting 449 properties that can cause human health effect when ingested continuously. Out of the 3 450 migration tests used, the UNE-EN 13130 method permitted identification of 451 compounds leaching from plastics and the ability to compare the migration levels with 452 legislative values. The ultrasonic extraction was an alternative to evaluate compounds 453 migrating from different polymers and qualitatively had a comparative performance 454 although with less efficiency and therefore, is not yet a validated and accepted method. 455 From 5 polymers tested, phthalates were not present in the plastics while NP and BPA 456 were identified at concentrations from 0.128 up to $3.423 \mu \mathrm{g} \mathrm{dm}{ }^{-2}$. PET and HDPE 457 bottles were the bottles with the lowest amount of EDCs. The biggest problem 458 compound was BPA which was detected in all polycarbonate bottled waters analyzed 459 and although the total daily intake was below the legislative values, it may contribute to 460 the total daily intake of this compound considering all types of food. Numerous studies 461 indicate that BPA causes adverse effects in experimental animals and the constant 462 exposure, metabolism and long term risk in humans is a matter of concern. The 463 European Food Safety Authority (EFSA), the US Environmental Protection Agency and 464 other Agencies are currently undertaking studies to integrate data from migration tests, 465 exposure levels and toxicity endpoints to assess the possible effects of BPA on humans 466 and initiate actions to protect human health. At this point, BPA has recently been 467 banned in Europe (by summer 2011).

468

469 Acknowledgments

470 This work was supported by “el Departament d'Universitats, Recerca i Societat de la 471 Informació de la Generalitat de Catalunya" and A. Guart acknowledges the "Agència de 472 Gestió d'Ajuts Universitaris i de Recerca (AGAUR)" in the context of the program 473 "Talent-Empresa (TEM 2009)" for the schoolarship. This study was financed by 474 "Ministerio de Educación y Ciencia" in the context of the project "Desarrollo y 
validación de un método analítico para la detección de residuos de plastificantes y surfactantes en aguas embotelladas" [PET2006_0615]. Jorge Oliver-Rodés is thanked for encouraging this study and for directing and facilitating the joint research activities. Dr. B. Oliver-Rodés and M. C. Pastor are thanked for their positive inputs and suggestions reflecting their long experience in the bottling sector. Dr. R. Chaler, D. Fanjul and M. Comesaña are acknowledged for their assistance with the GC-MS.

\section{References}

Biles JE, McNeal TP, Begley TH, Hollifield HC. 1997. Determination of Bisphenol-A in Reusable Polycarbonate Food-Contact Plastics and Migration to Food-Simulating Liquids. Journal of Agricultural and Food Chemistry 45: 3541-3544.

Biscardi D, Monarca S, De Fusco R, Senatore F, Poli P, Buschini A, Rossi C, Zani C. 2003. Evaluation of the migration of mutagens/carcinogens from PET bottles into mineral water by Tradescantia/micronuclei test, Comet assay on leukocytes and GC/MS. Science of the Total Environment 302: 101-108.

Bolgar M, Hubball J, Groeger J, Meronek S. 2008. Handbook for the chemical analysis of plastic and polymer additives. CRC Press, Taylor \& Francis Group. ISBN: 978-14200-4487-4.

Bredhult C, Sahlin L, Olovsson M. 2009. Gene expression analysis of human endometrial endothelial cells exposed to Bisphenol A. Reproductive Toxicology 28: $18-25$.

Calafat AM, Ye X, Wong LY, Reidy JA, Needham LL. 2008. Exposure of the U.S. population to bisphenol A and 4-tiertary-Octylphenol: 2003-2004. Environmental Health Perspectives 116, 39-44.

Casajuana N, Lacorte S. 2003. Presence and release of phthalic esters and other endocrine disrupting compounds in drinking water. Chromatographia 57: 649-655.

Casajuana N, Lacorte S. 2004. A new methodology for the determination of phthalate esters, Bisphenol A, Bisphenol A diglycidyl Ether and Nonylphenol in commercial whole milk samples. Journal of Agricultural and Food Chemistry 52, 3702-07.

Céspedes R., Raldúa D., Saura U., Piá P., Lacorte S., Viana P., Barceló D. 2004. Integrated protocol for the determination of endocrine disrupting activity in the surface waters and sediments using biological techniques by recombinant yeast assay and chemical analysis by LC-ESI-MS. Analytical Bioanalytical Chemistry 378, 697-708.

Council of Europe. 2002. Partial agreement in the social and public health fields, technical document. Vol. no 2.

European Food Safety Authority (EFSA), Scientific Panel on Food Additives, Flavouring, Processing Aids and Materials in Contact with Food. 2006. 2,2-Bis-(4hydroxyphenyl)propane (Bisphenol A). The EFSA Journal.

Environmental Protection Agency (EPA). 1993. Bisphenol A. Integration Risk Information System.

Environmental Protection Agency (EPA). 1997. Special Report on Envioronmental Endocrine Disruption: An Effects Assessment and Analysis.

Ghisari M, Bonefeld-Jorgensen EC. 2009. Effects of plasticizers and their mixtures on estrogen receptor and thyroid hormone functions. Toxicology Letters 189: 67-77. 
Huang H, Leung LK. 2009. Bisphenol A downregulates CYP19 transcription in JEG-3 cells. Toxicology Letters 189: 248-252.

Le HH, Carlson EM, Chua JP, Belcher SM. 2008. Bisphenol A is released from polycarbonate drinking bottles and mimics the neurotoxic actions of estrogen in developing cerebellar neurons. Toxicology Letters 176: 149-156.

Loyo-Rosales JE, Rosales-Rivera GC, Lynch AM, Rice CP, Torrents A. 2004. Migration of Nonylphenol from Plastic Containers to Water and a Milk Surrogate. Journal of Agricultural and Food Chemistry 52: 2016-2020.

Ministerio de la Presidencia. 2008. Spanish Royal Decree 866/2008. BOE 131, 2507025120.

Nerín C, Acosta D. 2002. Behavior of Some Solid Food Simulants in Contact with Several Plastics Used in Microwave Ovens. Journal of Agricultural and Food Chemistry 50, 7488-7492.

Nerín C, Fernández C, Domeño C, Salafranca J. 2003. Determination of potential migrants in polycarbonate containers used for microwave ovens by highperformance liquid chromatography with ultraviolet and fluorescence detection. Journal of Agricultural and Food Chemistry 51: 5647-5653.

Piringer OG, Baner AL. 2008. Plastic Packaging. Interactions with Food and Pharmaceuticals. WILEY-VCH. ISBN: 978-3-527-31455-3.

Peñalver A, Pocurull E, Borrull F, Marcé RM. 2000. Determination of phthalate esters in water samples by solid-phase microextraction and gas chromatography with mass spectrometric detection. Journal of Chromatography A 872: 191-201.

Rivas A, Olea N, Olea-Serrano F. 1997. Human exposure to endocrine-disrupting chemicals: Assessing the total estrogenic xenobiotic burden. TrAC - Trends in Analytical Chemistry 16: 613-619.

Salian S, Doshi T, Vanage G. 2009. Impairment in protein expression profile of testicular steroid receptor coregulators in male rat offspring perinatally exposed to Bisphenol A. Life Sciences 85: 11-18.

Schmid P, Kohler M, Meierhofer R, Luzi S, Wegelin M. 2008. Does the reuse of PET bottles during solar water disinfection pose a health risk due to the migration of plasticisers and other chemicals into the water? Water Research 42: 5054-5060.

Shen HY, Jiang HL, Mao HL, Pan G, Zhou L, Cao YF. 2007. Simultaneous determination of seven phthalates and four parabens in cosmetic products using HPLC-DAD and GC-MS methods. Journal of Separation Science 30: 48-54.

Unit on food contact materials, enzymes, flavourings and processing aids (CEF), Unit on Assessment Methodology (AMU). 2008. Statement of EFSA on a study associating bisphenol A with medical disorders. The EFSA Journal.

UNE-EN 1186. Materials and articles in contact with foodstuffs. Plastics. 2002.

UNE-EN 13130. Materials and articles in contact with foodstuffs - Plastics substances subject to limitation. 2005.

UNE-EN ISO 177. Plastics. Determination of migration of plasticizers. 1988.

The Commission of the European Communities. 1982. Directive 82/711/EC. Official Journal of the European Union.

The Commission of the European Communities. 1985. Directive 85/572/EEC. Official Journal of the European Union.

The Commission of the European Communities. 2007. Directive 2007/19/EC. Official Journal of the European Union.

Vandenberg LN, Hauser R, Marcus M, Olea N, Welshons WV. 2007. Human exposure to bisphenol A (BPA). Reproductive Toxicology 24: 139-177. 
570 World Packaging Organisation (WPO). 2008. Market Statistics and Future Trends in 571 Global Packaging. www.worldpackaging.org. Formato Design-Brazil.

572

573

574 
Table 1. Plasticizers and additives studied, their molecular formula, water octanol coefficient (log Kow), toxicity using Daphnia magna and Recombinant Yeast Assay (RYA), limits of detection calculated from 3 times the standard deviation of the blank samples (n=5), recoveries calculated at $1 \mu \mathrm{g} \mathrm{L}{ }^{-1}$ and legislated values.

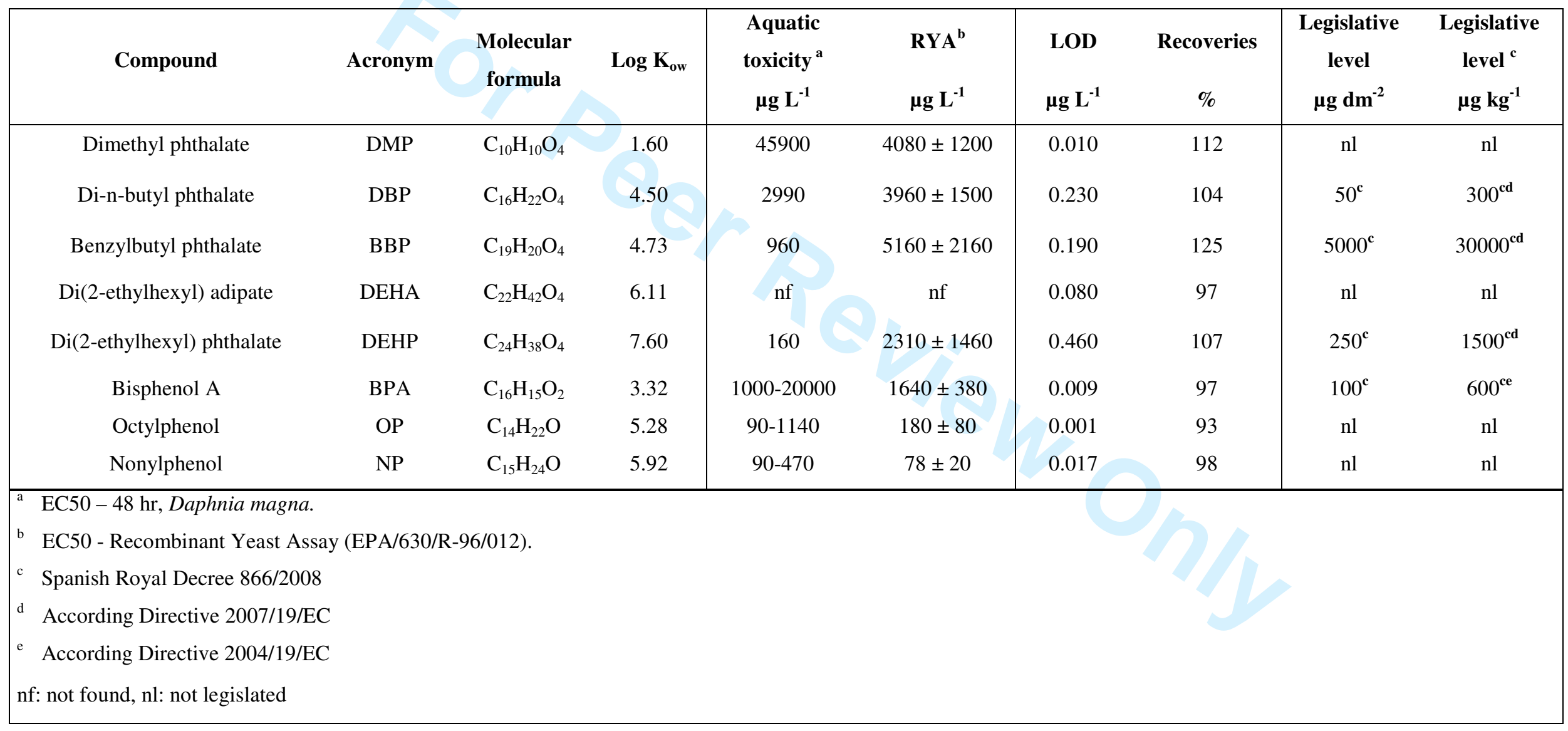


Table 2. UNE-EN ISO 177 weights for 4 test plastics where it is observed that plastics lose weight while the adsorbent gains weight.

\begin{tabular}{|c|c|c|}
\hline & $\Delta$ m plastic mg & $\Delta \mathbf{m}$ disks mg \\
\hline PET bottle & -0.3 & 8.1 \\
\hline HDPE bottle & -2.7 & 5.0 \\
\hline PC bottle & 0.1 & 2.4 \\
\hline HDPE cap & -5.1 & 5.9 \\
\hline Blank & - & 0.3 \\
\hline
\end{tabular}


Table 3. Compounds identified using ultrasonic extraction and the conditions specified in UNE-EN 13130 expressed in mg $\mathrm{dm}^{-2} \mathrm{of}_{\mathrm{plastic}} \pm$ standard deviation and \% recoveries of target compounds in the $1 \mu \mathrm{g} \mathrm{L}^{-1}$ spiked HPLC water quality control.

\begin{tabular}{|c|c|c|c|c|c|c|c|c|}
\hline \multirow[b]{2}{*}{ Method } & \multirow{2}{*}{ Compound } & \multicolumn{3}{|c|}{ Bottles } & \multicolumn{2}{|c|}{ Caps } & \multirow{2}{*}{$\begin{array}{c}\text { Septum } \\
\text { PS } \\
\mu \mathrm{g} \mathrm{dm}^{-2}\end{array}$} & \multirow{2}{*}{$\begin{array}{c}\text { Recov. } \\
(\%)\end{array}$} \\
\hline & & $\begin{array}{c}\text { PET } \\
\mu \mathrm{g} \mathbf{d m}^{-2}\end{array}$ & $\begin{array}{c}\text { HDPE } \\
\mu \mathrm{g} \mathrm{dm}^{-2}\end{array}$ & $\begin{array}{c}\mathrm{PC} \\
\mu \mathrm{g} \mathrm{dm}^{-2}\end{array}$ & $\begin{array}{c}\text { HDPE } \\
\mu \mathrm{g} \mathrm{dm}^{-2}\end{array}$ & $\begin{array}{c}\text { LDPE } \\
\mu \mathrm{g} \mathrm{dm^{-2 }}\end{array}$ & & \\
\hline \multirow{2}{*}{$\begin{array}{l}\text { Ultrasonic } \\
\text { extraction }\end{array}$} & $\mathbf{N P}$ & $<\mathrm{LOD}$ & $0.242 \pm 0.005$ & $<\mathrm{LOD}$ & $<\mathrm{LOD}$ & $<\mathrm{LOD}$ & $0.212 \pm 0.034$ & 45 \\
\hline & BPA & $<\mathrm{LOD}$ & $<$ LOD & $1.870 \pm 0.088$ & $<\mathrm{LOD}$ & $<\mathrm{LOD}$ & $<\mathrm{LOD}$ & 76 \\
\hline \multirow{2}{*}{$\begin{array}{c}\text { UNE-EN } \\
13130\end{array}$} & NP & $0.332 \pm 0.022$ & $0.579 \pm 0.008$ & $0.694 \pm 0.091$ & $1.282 \pm 0.178$ & $0.413 \pm 0.004$ & $0.801 \pm 0.176$ & 92 \\
\hline & BPA & $<\mathrm{LOD}$ & $<$ LOD & $3.423 \pm 0.217$ & $0.145 \pm 0.026$ & $0.128 \pm 0.019$ & $0.136 \pm 0.028$ & 97 \\
\hline
\end{tabular}


Figure 1. Illustration of the three tests.

(i) UNE-EN ISO 177
Scheme of the "sandwich" system

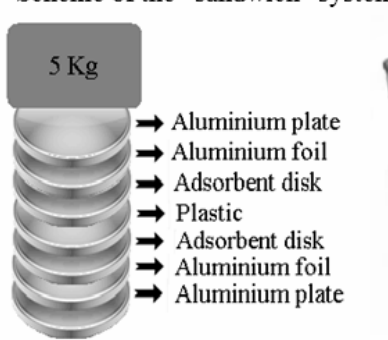

(ii) Ultrasonic bath

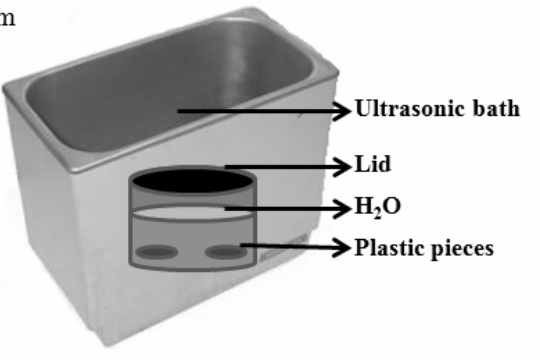

(iii) UNE-EN 13130

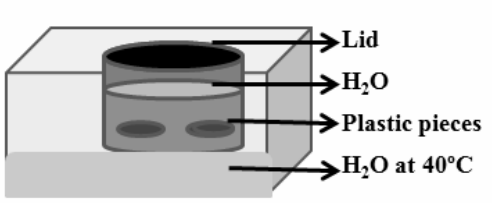


Figure 2. GC-MS TIC chromatogram of PC sample with UNE-EN 13130 method.

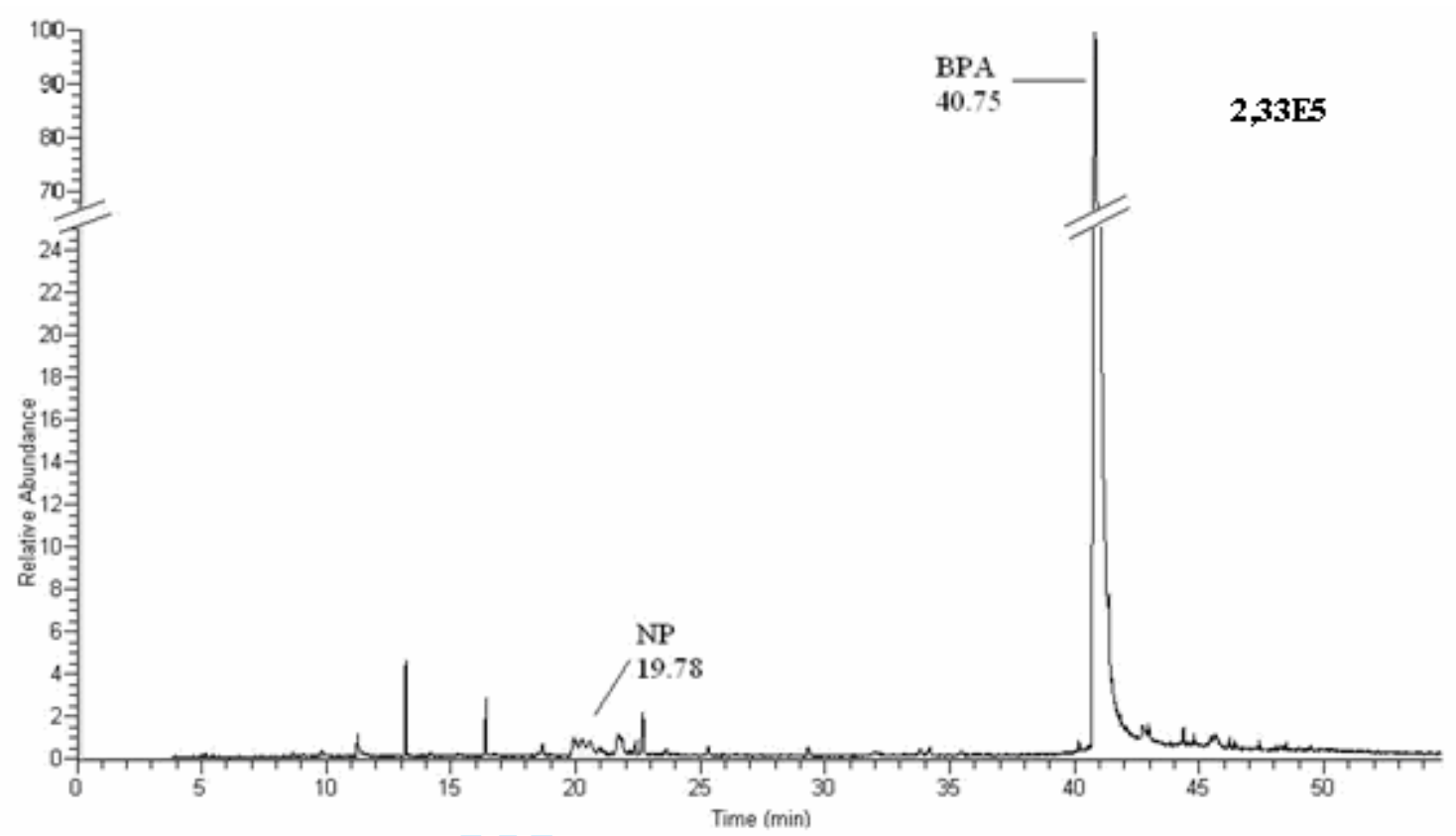

